\title{
Financial and Institutional Reforms for an Entrepreneurial Society
}

\author{
Claire Economidou • Luca Grilli • \\ Magnus Henrekson • Mark Sanders
}

Accepted: 31 December 2017 /Published online: 8 March 2018

(C) The Author(s) 2018. This article is an open access publication

\begin{abstract}
In this paper, we introduce the special issue on Financial and Institutional Reforms for an Entrepreneurial Society in Europe. There are many reasons for Europe to want to make the transition to a more Entrepreneurial Society. And for decades now, policy makers are trying to bring that transition about with variations on the "educate, deregulate and finance" approach to entrepreneurship. We argue that more fundamental reforms are required to improve the entrepreneurial ecosystem and bring about this transition. We then discuss the 12 contributions that pertain to five different facets of the entrepreneurial ecosystem. The first two papers address the most fundamental institutional foundations of the ecosystem. The next three papers discuss the (lack of) access to knowledge and incentives to start innovative entrepreneurial
\end{abstract}

\section{Economidou}

Department of Economics, University of Piraeus, Piraeus, Greece e-mail: economidou@unipi.gr

\section{Grilli}

Department of Management, Economics and Industrial Engineering, Politecnico di Milano, Milan, Italy

e-mail: luca.grilli@polimi.it

\section{Henrekson}

Research Institute of Industrial Economics (IFN), Stockholm, Sweden

e-mail: Magnus.Henrekson@ifn.se

M. Sanders $(\bowtie)$

Utrecht University School of Economics (USE), Utrecht,

Netherlands

e-mail: m.w.j.1.sanders@uu.nl ventures. That is followed by three papers that focus on the institutions that (fail to) channel financial resources to such ventures and two papers that analyze the relevance of labor market institutions. The special issue concludes with two papers investigating how the interplay of institutions and productive entrepreneurship results in economic growth.

Keywords Entrepreneurship · Institutions · Reform · European Union · Innovation

JEL classification $\mathrm{D} 02 \cdot \mathrm{L} 26 \cdot \mathrm{O} 38 \cdot \mathrm{O} 43 \cdot \mathrm{P} 11$

The European Union, in its Horizon 2020 program in 2015, invited researchers to develop evidence-based strategies to put Europe back on track to a situation of sustainable, inclusive, and innovative growth. In their call, however, the word "entrepreneurship" was entirely absent. We believe entrepreneurship is at the heart of this challenge. And indeed, the European Commission itself intuitively recognizes the importance of entrepreneurship. At the launch of the Innovation Union, they state: "We need to do much better at turning our research into new and better services and products if we are to remain competitive in the global marketplace and improve the quality of life in Europe." And to emphasize the urgency of this challenge, the Commission continues: "We are facing a situation of 'innovation emergency'."1

\footnotetext{
${ }^{1}$ Cited from http://ec.europa.eu/research/innovation-union/index_en.
} cfm?pg=why (accessed November 17, 2017); bold in the original. 
This rather stark conclusion followed from the observation that European member states are gradually slipping out of the top positions in global rankings on innovation. The most recent rankings of the top 20 countries, according to the most commonly used measures for innovativeness, are presented in Table 1. One can tell two stories with this table. On the one hand, the USA consistently ranks higher than most European countries, many Asian countries are rising fast, and Singapore and Hong Kong already outperform most EU member states on all rankings. On the other hand, half the top 20 countries in all these rankings are still European, and particularly, the Nordic and Western European countries continue to do well. The table furthermore reveals the well-known core-periphery pattern in Europe. ${ }^{2}$

The emphasis on such rankings is without doubt important, but competitiveness, patents, and innovation per se will not automatically result in growth and increased prosperity (Acs et al. 2009; Acs and Sanders 2013). They are necessary but by no means sufficient ingredients in the growth process. To transform these ingredients into inclusive and sustainable growth, entrepreneurs must exploit the new knowledge and diffuse the innovations into the marketplace. If good ideas do not make it to global markets fast enough, knowledge creation alone will not fuel inclusive and sustainable growth.

Entrepreneurship, broadly defined as the act of challenging the status quo by introducing novelty into the economic realm, must then be a central theme. ${ }^{3}$ Schumpeterian entrepreneurs introduce new products and technologies and act as conduits of knowledge to generate innovation and growth (Schumpeter 1934). Kirznerian entrepreneurs ensure that these new technologies, opportunities, and products diffuse, and thereby, the benefits of innovation trickle down and out

\footnotetext{
${ }^{2}$ The southern and eastern EU member states are absent in most rankings. Such patterns arguably also exist in the USA and China, but there, they are obscured by the focus on national averages.

${ }^{3}$ We do not want to get bogged down here in a discussion on what exactly defines and delimits entrepreneurship. As Acs et al. (2014, p. 476) state: "In spite of years of research, entrepreneurship is a fiendishly difficult concept to pin down"; and Anderson and Starnawska (2008, p. 224) noted: "more than two decades of concentrated endeavor have failed to produce a universally acceptable definition of entrepreneurship". Entrepreneurship is a multifaceted, multidimensional, and contextual phenomenon that is defined almost tautologically by what it does as much as by what it is. For this introduction, we define it as broadly as in the text above, but leave it to the different contributors to possibly provide their own definitions.
}

to the periphery, making growth inclusive (Kirzner 1973). Both processes typically need the formation of new organizations as incumbents have a vested interest in the status quo and as such are less likely to lead the transition to a more sustainable economic system (Aghion and Howitt 1992; Carlsson 1999). Productive entrepreneurship makes transitions happen, but we also know that such entrepreneurship cannot be taken for granted. If Europe wants more of it, it will have to change its ways.

Since Baumol (1990), it is understood that the institutional framework, broadly defined as "the rules of the game" (North 1991), determines whether the available entrepreneurial talent is directed into socially productive activities. The rules of the game must both encourage effort and direct that effort towards socially beneficial venturing. In addition, they need to allow for innovative ideas to challenge the status quo, reward success, and tolerate failure, thereby fostering the dynamics of creative destruction. This is the Entrepreneurial Society in a broad sense (Audretsch 2007; Audretsch and Thurik 2000). In such a society, entrepreneurship is key in creating the diverse and open contestable markets that constitute the selection environment in which innovations can shape the future. By introducing new varieties into this open selection environment, entrepreneurs can generate growth, jobs, prosperity, and opportunities for all. Empowering entrepreneurs to create new variety under the right institutional preconditions therefore seems the way forward. The question then becomes, what institutions matter most? We propose that entrepreneurs can only fulfill their function in the Entrepreneurial Society if they have adequate access to knowledge, labor, and financial resources.

Any challenge to the status quo necessarily starts with an idea. That idea can come from anywhere, but it has a much better chance of being sensible, if it brings together relevant knowledge around a problem that is also well understood. Access to knowledge is therefore a precondition for productive entrepreneurship. To then develop the sensible idea into a venture, an entrepreneur will need financial and human resources or capital and labor, broadly defined. Of course, a venture then needs much more, including no small measure of luck, to succeed and grow into a sizable firm and global industry leader. But the functioning of the Entrepreneurial Society should not only be measured by the number of successful ventures it boasts at any given point in time. It is equally important to consider the number of challengers it 
Table 1 Country ranking according to the five most commonly used measures of national innovativeness, top 20 countries for the last available year

\begin{tabular}{|c|c|c|c|c|c|}
\hline Rank & $\begin{array}{l}\text { IMD World } \\
\text { Competitiveness } \\
\text { Ranking } 2017\end{array}$ & $\begin{array}{l}\text { WEF Global } \\
\text { Competitiveness Index } \\
\text { 2017-2018 }\end{array}$ & $\begin{array}{l}\text { Global Innovation Index } 2017 \\
\text { (INSEAD, Cornell, WIPO) }\end{array}$ & $\begin{array}{l}\text { No. of Triadic } \\
\text { Patents per Capita } \\
\text { 2013* }\end{array}$ & $\begin{array}{l}\text { R\&D Spending as a } \\
\text { Share of GDP } 2015\end{array}$ \\
\hline 1 & Hong Kong & Switzerland & Switzerland & Switzerland & Israel \\
\hline 2 & Switzerland & USA & Sweden & Japan & South Korea \\
\hline 3 & Singapore & Singapore & Netherlands & Germany & Switzerland \\
\hline 4 & USA & Netherlands & USA & Sweden & Japan \\
\hline 5 & Netherlands & Germany & UK & Denmark & Sweden \\
\hline 6 & Ireland & Hong Kong & Denmark & South Korea & Austria \\
\hline 7 & Denmark & Sweden & Singapore & Austria & Taiwan \\
\hline 8 & Luxembourg & UK & Finland & Netherlands & Denmark \\
\hline 9 & Sweden & Japan & Germany & Israel & Germany \\
\hline 10 & UAE & Finland & Ireland & USA & Finland \\
\hline 11 & Norway & Norway & South Korea & Finland & USA \\
\hline 12 & Canada & Denmark & Luxembourg & Belgium & Belgium \\
\hline 13 & Germany & New Zealand & Iceland & France & France \\
\hline 14 & Taiwan & Canada & Japan & Luxembourg & Slovenia \\
\hline 15 & Finland & Taiwan & France & UK & Iceland \\
\hline 16 & New Zealand & Israel & Hong Kong & Norway & Singapore $^{1}$ \\
\hline 17 & Qatar & UAE & Israel & Ireland & Australia $^{2}$ \\
\hline 18 & China & Austria & Canada & Canada & China \\
\hline 19 & UK & Luxembourg & Norway & Australia & Netherlands \\
\hline 20 & Iceland & Belgium & Austria & Italy & Czech Republic \\
\hline
\end{tabular}

${ }^{1} 2014$

${ }^{2} 2013$

*Triadic patent families are a set of patents filed at three of the major patent offices: the European Patent Office (EPO), the Japan Patent Office (JPO), and the United States Patent and Trademark Office (USPTO). Patents included in the triadic family are typically of higher economic value.

Sources: IMD World Competitiveness Yearbook 2017; World Economic Forum, Global Competitiveness Report 2017-2018; The Global Innovation Index 2017-Innovation Feeding the World (INSEAD, Cornell University and WIPO); OECD Factbook 2015-2016: Economic, Environmental and Social Statistics; OECD Statistics

continuously supports, as that is what drives the process of creative destruction. And for that, more small, experimental, young ventures should be able to gain access to the resources they need.

What institutional reforms could improve that access was the topic of this special issue and the consortium we formed with the ambition to develop a strategy for Financial and Institutional Reforms for an Entrepreneurial Society (FIRES) in Europe. We would argue that assembling this special issue and working together on the challenge in a focused and policy-oriented way has furthered our understanding of the complex relations between the locally specific, multilayered, often historically evolved institutions that perform key functions in the entrepreneurial ecosystem (e.g., Autio 2016; Elert et al. 2017). Such understanding is a prerequisite for designing interventions to (re)shape institutions to promote productive entrepreneurship. We believe that this special issue will help to gain new insights and improve our understanding of the issues involved and, most importantly, motivate scholars to contribute a piece of the puzzle in future work.

Our special issue consists of 12 contributions that pertain to five different aspects or facets of the entrepreneurial ecosystem. The first two papers address the most fundamental institutional foundations of the ecosystem. The next three papers discuss the (lack of) access to 
knowledge and incentives to start innovative entrepreneurial ventures. This is followed by three papers that focus on the institutions that (fail to) channel financial resources to such ventures and two papers that analyze the relevance of labor market institutions. The special issue concludes with two papers investigating how the interplay of institutions and productive entrepreneurship results in economic growth. We acknowledge financial support from the EU project FIRES (grant agreement number 949378) for making all the contributions to this special issue available under Open Access.

In the remainder of this introduction, we discuss these five key aspects and how the individual contributions relate to each other and to the overall theme of the special issue. We conclude by discussing the most important implications for an effective reform strategy towards a more Entrepreneurial Society as well as for a future research agenda.

\section{The basic institutional framework}

An Entrepreneurial Society that generates inclusive, sustainable, and innovative economic growth rests on a sound institutional framework that channels society's financial resources, knowledge, and talent to productive entrepreneurship (Baumol 1990). The first paper in this special issue Dilli et al. (2018), maps out the key institutions that together make up this framework. Based on the "varieties of capitalism" literature (Hall and Soskice 2001), the authors investigate what clusters of related and interacting institutions promote entrepreneurship. They find that different clusters of institutional arrangements can perform similar functions. The authors collected and analyzed data on 20 European countries and the USA and show how a core set of institutions, governing the exchange between entrepreneurial ventures and their shareholders, workforces, and R\&D partners, differ systematically across countries and how these institutional constellations facilitate the development of different types of entrepreneurship. From this paper, and several others in the literature (e.g., Hall and Jones 1999; Henrekson and Johansson 2009; Bjørnskov and Foss 2013), we may conclude that the rule of law is a necessary condition for the Entrepreneurial Society. However, any remedial suggestions must take current conditions into account. This is illustrated by Operti (2018) in her study of organized crime in Italy. She shows that the fight against organized crime, and more specifically the aggressive confiscation of criminal wealth, may have unintended consequences for entrepreneurship. Her study demonstrates in a concrete and specific context how institutions and behavior interact to shape the Entrepreneurial Society in complex ways. This study is not a call for facilitating the activities of organized crime, as that would clearly redirect a great deal of entrepreneurial effort towards unproductive or destructive venturing. It does, however, show that reforming institutions can have unintended consequences and even the most unlikely institutions may be tied to entrepreneurial venturing.

\section{Knowledge}

A society's ability to increase its wealth and welfare over time critically relies on its potential to develop, exploit, and diffuse knowledge. The role of entrepreneurship is crucial in exploiting and diffusing the knowledge created. New businesses in general and innovative start-ups, in particular, can be regarded as manifestations of knowledge spillovers from existing knowledge sources (Acs et al. 2009, 2013). However, there are considerable spatial differences in entrepreneurship activity, which tend to be highly persistent over long periods of time (Andersson and Koster 2011; Fotopoulos and Storey 2017; Fritsch et al. 2017). Such differences can be attributed to knowledge institutions, culture traditions, knowledge training, and government regulations and actions among other factors.

In this special issue, the persistence of spatial differences in entrepreneurship activity are studied by Fritsch and Wyrwich (2018), who explore the role of the historical knowledge base and entrepreneurial culture of a region on current levels of new business formation in innovative industries in German regions for the period 1907-2014. Their findings support a pronounced positive relationship between high levels of historical selfemployment in science-based industries and new business formation in innovative industries today. Furthermore, positive interaction effects are also documented between the presence of technical universities, founded more than a century ago, and the general level of historical entrepreneurship on current start-up activity. The long-term legacy effect that emerges in their analysis indicates that the prevalence of historically rooted 
institutions is driving knowledge spillovers and entrepreneurship.

Dilli and Westerhuis (2018) examine the role of human capital accumulation by topic and focus on the importance of Science, Technology, Engineering and Math (STEM) education and the persistent gender differences therein for a large panel of European countries and the USA. The authors find that countries with greater gender equality in STEM education are characterized by higher entrepreneurial activity in knowledgeintensive sectors and high growth aspirations. Consequently, next to individual-level education, closing the gender gap in STEM education can be expected to stimulate innovative entrepreneurial activity. A policy implication of their analysis is that policies should aim to close the gender gap in STEM education at the tertiary level, but to do so, gender differences should be targeted at earlier stages of the life cycle.

Darnihamedani et al. (2018) take a more direct approach to innovative entrepreneurship and investigate how taxation and start-up costs affect the entrepreneurial channel for knowledge spillovers. Taxes and start-up costs (notary charges or registration) may influence knowledge diffusion by discouraging innovative entrepreneurial activity (see Blackburn and Schaper 2016 for an extensive literature review). High start-up costs not only reduce entrepreneurship rates but may also influence the quality and type of entrepreneurship. To date, a large literature covers the effects of taxes and start-up costs on entrepreneurship rates (Gentry and Hubbard 2000; Djankov et al. 2002; Lundström and Stevenson 2005; Klapper et al. 2006; Braunerhjelm and Eklund 2014). However, this literature largely overlooks the quality implications of such barriers. Darnihamedani et al. (2018) offer additional insights by differentiating between innovative, knowledge intensive, and noninnovative entrepreneurship activity. Based on a large sample of 43,223 entrepreneurs from 53 countries, they find that corporate taxes are negatively related to innovative entrepreneurship, while income taxes are found to have no effect. High start-up costs seem to deter mainly non-innovative entrepreneurs. As a result, Darnihamedani et al. suggest that governments can stimulate innovative entrepreneurship by tying costs less directly to the rewards of innovation. If the goal is to promote innovative business activities and growth, taxes on property and goods are preferred over taxes on income and profit. When it comes to start-up costs, the implications are less straightforward. Lowering such costs can increase the rate of entrepreneurship, leading to less unemployment and a more dynamic business environment. But lowering start-up costs may also decrease knowledge spillovers due to (excessive) entry of imitative entrepreneurs and lower expected returns on innovation. Once the right people have become entrepreneurs and started their ventures with the required skills and knowledge, their venture needs finance to grow; thus, we turn our attention to finance.

\section{Finance}

A vibrant entrepreneurial finance sector is deemed to be a fundamental precondition for triggering the virtuous dynamics characterizing an Entrepreneurial Society. However, innovative startups are often financially constrained, and the information asymmetry between lenders and borrowers has led to the establishment of specialized financial intermediaries called venture capital (VC) firms. VC firms are reputed to be more capable than other actors in financial markets to deal with the high level of uncertainty and the many principal agent problems in the startup sector (Gompers and Lerner 2001). Despite the well-documented relevance of $\mathrm{VC}$, there are considerable differences in VC activity across countries. The VC sector is small in continental Europe (notably in France, Italy, and Spain) and in some countries negligible (Greece, Poland, Czech Republic, and Romania).

Grilli et al. (2018) analyze the institutional determinants of VC in Europe. Based on longitudinal countrylevel data for 18 European countries during the 19972015, they first explore whether "the usual suspects" mostly represented by changeable formal institutions (i.e., investor protection laws, tax codes, and labor market regulations) play a role in the European context. Then, they investigate whether social capital, a deepseated informal institutional feature, may also exert a significant effect. Last, they test how structural formal institutions (e.g., rule of law and government effectiveness) influence the development of the VC industry. Their analysis indicates that social capital does play a role in explaining cross-country differences in the extent of VC activity. Moreover, they find evidence that this role is indirect: the impact of social capital structures on $\mathrm{VC}$ is mainly channeled through their role in establishing those structural formal institutions which are of key importance for the development of a VC industry. The main overall finding of their analysis is that $\mathrm{VC}$ is 
mostly influenced by hard-to-change informal institutional features. Based on this finding, the authors suggest the presence of a sort of European "institutional misalignment" towards VC as a key reason behind the endemic lack of this type of finance in most European countries. The only changeable formal institution that is found to play a non-negligible role is the tax code. By contrast, reforms aimed at increasing flexibility in labor markets or investor protection do not seem to affect VC activity.

These results are condensed into two policy recommendations. First, although the introduction of more VC-friendly institutions is advisable given its beneficial effect on start-ups, European policy makers should also turn their attention to fintech innovations that in the medium to long term may dramatically change the way start-ups will be able to finance themselves. This may prove to better fit the European "institutional matrix" (North 1991). In this respect, the analysis carried out by Estrin et al. (2018) on the emergence and characteristics of a thick equity crowdfunding market in the London area is instructive both regarding the distinctive features of this new form of entrepreneurial finance and regarding the regulatory aspects that need to be taken into consideration.

Second, as far as policy measures fostering VC are concerned, well-designed and targeted changes in the tax code appear to be the most promising avenue. This is supported by the analysis carried out by Henrekson and Sanandaji (2018). They find a strong correlation at a worldwide level between the tax treatment of employee stock options and VC activity. A major advantage of this tax policy is that it narrowly targets entrepreneurial startups without requiring broad tax cuts. Accordingly, they suggest that a well-designed reform of the taxation of stock options and similar instruments along the lines of the US reform around 1980 would cost the government little in terms of foregone tax revenue. It would therefore be a cost-effective reform for improving the European ecosystem for new high-growth firms.

In addition to finance, human capital is a second resource that promising ventures must manage to grow in line with its potential. Even if the idea is good and finance is available, joining a startup is a risky career choice. Moreover, entrepreneurs also face a trade-off between building a new venture based on their idea or finding more secure wage employment. If the opportunity cost of becoming or joining an entrepreneur is too high, or alternatively, the expected benefits are too low to compensate for the risk incurred, a person may rationally decide not to follow up on good ideas, even if finance and knowledge are available. This brings us to labor market institutions.

\section{Labor}

An Entrepreneurial Society requires a flexible labor market where people are willing and able to engage in entrepreneurial ventures themselves, or to join the ventures of others. This is especially relevant for the skilled and experienced employees and entrepreneurs. Hence, there is an obvious link between labor market institutions and the Entrepreneurial Society. Research has found that labor market regulations shape the level of nascent entrepreneurship. Consequently, entrepreneurship is higher in countries in which hiring and dismissing employees is relatively easy and inexpensive (Niehof 1999; OECD 2003; van Stel et al. 2007). In addition, labor market liberalization has been connected to entrepreneurial activity in many OECD countries (OECD 1998, 2000), and Europe's strict employment protection legislation has been connected to its lower frequency of new, rapidly growing firms relative to the USA (Baumol et al. 2007, p. 210 and 222). ${ }^{4}$

The extensive European welfare states are also closely linked to the labor market. Social security systems in combination with strict labor security legislation tend to penalize individuals who undertake entrepreneurial risk (Ilmakunnas and Kanniainen 2001). This is particularly relevant when systems confer many social security benefits, such as disability, sickness, unemployment, and pension insurance, explicitly linked to formal employment. Such benefits increase the opportunity cost of leaving a tenured position and effectively become a marginal tax on entrepreneurship (Audretsch et al. 2002; Henrekson 2014).

\footnotetext{
$\overline{{ }^{4} \text { Stringent labor }}$ market regulations thus deter and impede business activities but may simultaneously boost self-employment due to evasive measures. To circumvent stringent regulations, potential entrepreneurs can choose to become self-employed themselves. They could also decide to eschew hiring employees in favor of cooperating in networks with other self-employed individuals since no labor security is mandated for the self-employed and compensation and working hours are unregulated. However, this type of self-employment should not be interpreted as a sign of entrepreneurial dynamism but instead as a costly, albeit necessary, strategy to evade onerous regulation. Part of the increase in self-employment in recent years in many highlyregulated economies is likely driven by such considerations (Liebregts and Stam 2016).
} 
Under such circumstances, it becomes rational not to forgo social protection in exchange for an uncertain entrepreneurial income. Making parts of social insurance benefits "portable" over jobs and labor market positions would mitigate this problem. Evidence to support the hypothesis that strict employment protection limits the mobility of people and thereby inhibits the flow of talent to entrepreneurial ventures would support policies and reforms in that direction. Some of that evidence is found in the paper by Fu et al. (2018). This paper takes a nuanced approach and investigates the impact of strict labor protection on the re-entry of experienced entrepreneurs from paid employment and unemployment, respectively. They show that, in a sample of more than 15,000 individuals from 29 European countries, the probability of re-entering as an entrepreneur is higher in strict employment protection regimes, higher for employed people with prior entrepreneurial experience, and more so for the employed in strict protection regimes. This implies that strict labor market protection stimulates (or forces) the experienced entrepreneurs to re-enter entrepreneurship. This group of experienced entrepreneurs is particularly important, as they have been shown to create more jobs and build more productive ventures. However, the results cannot be taken to support a policy of even stricter labor market regulations. Instead, the results can be interpreted to mean that strict employment protection keeps those without prior entrepreneurial experience locked up in their gilded cage, whereas those who tried entrepreneurship earlier in their careers are locked out of the protected labor market. Fu et al. do not cover the impact that strict labor market policies might have on the willingness of people to work in entrepreneurial ventures, but in their discussion of the results, they show that they are aware of the dangers of rigid labor market segmentation.

The paper by Held et al. (2018) approaches the issue from a different angle. By interviewing entrepreneurs and carefully recording how and when they formed the team and the subsequent venture by recruiting co-founders, employees, and service providers, they aim to show that these processes differ systematically across ventures and countries. The data intensity of the method precludes comparative analyses of venture creation processes in many countries, but by comparing Germany and the USA, Held et al. give us a first impression of the possible impact of labor market regulations. They show that, despite variety in venture creation processes within these countries, cross-country differences help explain the choices entrepreneurs make in the sequencing, timing, and formation of their teams. At this stage, it is not clear whether these differences are causally linked to labor market institutions, but this issue constitutes an obvious question for future research.

With institutions giving potential ventures access to required finance, knowledge, and human capital, we should expect more experimentation and disruptive innovation. Eventually, that should translate into innovative, inclusive, and sustainable economic growth. The proof of the pudding is, of course, in the eating, but empirically linking typically endogenous, multidimensional, and often hard-to-define variables like growth, entrepreneurship, and institutions is far from trivial.

\section{Growth}

Ultimately, the importance of entrepreneurship boils down to its consequences for the wellbeing of individuals and society. This impact can be measured in many ways, but an obvious relationship to assess is the link between income and entrepreneurship. ${ }^{5}$ In this special issue, there are two papers that investigate this link at the aggregate level. Bosma et al. (2018) build on well-established growth regressions that can be directly derived from the neoclassical growth model and test the link in growth specifications proposed by Mankiw et al. (1992) and Islam (1995). Estimating classical growth regressions for a sample of 25 European countries in the period 2003-2014 and testing down a list of common indicators for entrepreneurial activity reveals that entrepreneurship and per capita GDP growth are positively related. The robustness of this relationship is tested and supported by estimating a 3SLS model that simultaneously links institutions to entrepreneurship and entrepreneurship to growth.

An interesting alternative approach is presented by Acs et al. (2018). They estimate a production function in logged first differences for a panel of 46 countries in the period 2002-2011. This paper explores the interaction between institutions and entrepreneurship by introducing a composite index for entrepreneurial activity and

\footnotetext{
${ }^{5}$ At the aggregate level, one immediately faces the problem of somehow measuring entrepreneurship across institutional clusters, i.e., countries (see Acs et al. (2014) and Henrekson and Sanandaji (2017) for a discussion of the issues and solutions that have been proposed in the literature). The papers presented in this special issue both contribute to this broader debate.
} 
institutional quality. This index is also decomposed in its institutional and entrepreneurial components. The authors then show that improvements in the combined index contribute to economic growth, while plain increases in entrepreneurial activity do not.

Both Bosma et al. and Acs et al. stress the importance of the institutional environment in shaping the orientation and impact of entrepreneurial activity; both individually and together, these two studies shed light on this question. In a sample restricted to EU countries, the results suggest that the contribution of institutions to growth runs through productive entrepreneurial activity. In the broader sample including developing countries, entrepreneurial activity and institutional quality are shown to be complements that contribute most to economic growth in combination. As the modeling approaches in these papers are not nested and results cannot be directly compared, the two papers suggest an interesting agenda for future research that we discuss in our conclusion.

\section{Conclusions and agenda for future research}

From the work presented in this special issue, we draw some preliminary conclusions and draft an agenda for future research. In Table 2, we list the most salient policy implications and points for the agenda for future research that emanate from the studies collected in this issue.

Going over the table in more detail, we can conclude that entrepreneurship policy must be contextualized and embedded in institutions. That is, entrepreneurship is both an outcome and a proximate cause of the inclusive, sustainable, and innovative growth that the European Union is aiming for. The ultimate causes reside in the complex institutional body that brings forth the entrepreneurial activity we observe. Keeping this in mind, we conclude that any policy intervention must be carefully tailored to the existing institutional framework (Dilli et al. 2018), and changing the institutional setting may have unintended consequences even on the type of entrepreneurship that a specific reform was intended to foster (Operti 2018). However, this does not mean we should let history run its course and hope luck will be on our side (Fritsch and Wyrwich 2018). Targeted interventions in formal institutions can be made and designed to promote a more entrepreneurial culture. And specifically, interventions in the educational system can level the playing field and unlock the potential of women, migrants, and disadvantaged groups in formal labor markets (Dilli and Westerhuis 2018). Such interventions would channel more knowledge into entrepreneurship. If coupled with high entry barriers and strong incentives (Darnihamedani et al. 2018), knowledge-intensive entrepreneurship will be more innovative and productive. Everybody is not an entrepreneur and everybody should not be one. However, selection into entrepreneurship should be determined by relevant aspects of the venture, not irrelevant ones pertaining to prospective entrepreneurs. In general, it is not possible to pick winners, but an entrepreneurial culture embedded in a sophisticated entrepreneurial ecosystem backs the challengers and allows winners to pick themselves. It is important to guarantee access, especially to knowledge resources for everyone. That creates an inclusive society that efficiently allocates resources to those best equipped to pursue opportunities and tackle challenges. Combining broad access to knowledge resources and high returns to success in entrepreneurship with significant entry barriers will cause self-selection of the most promising entrepreneurs out of the largest pool of potential candidates. While this hypothesis needs further testing, preferably in rigorous policy experiments, it provides an initial step towards engineering a more entrepreneurial culture.

Such innovative entrepreneurship typically needs external finance, financial resources that the European bank-based and inflexible financial systems do not provide. It is an open question whether promoting US-style venture capital (Grilli et al. 2018; Henrekson and Sanandaji 2018), platform-based fintech solutions (Estrin et al. 2018), or perhaps a return to more traditional forms of relationship-based bank finance fit best in the European context. Policy experimentation by individual member countries is called for to find the best way forward in improving the access to external financing of innovative entrepreneurship. The focus on, and push towards, security and stability that followed the financial crisis of 2007-2011 should not result in an inability to assume risk in the real economy. Without entrepreneurial experimentation, we risk failing to develop the innovations that create the jobs and techniques that we need for inclusive and sustainable growth. Such policy experiments, as proposed in this special issue, should involve lower taxes and liberalization in well-defined areas and categories of taxation. Targeted interventions in the tax code may go a long way in promoting VC activity (Grilli et al. 2018; Henrekson and Sanandaji 2018). But the proposed policy reforms should be designed as experiments. That is, policies should be designed to test the hypotheses and establish causal links. Taken 
Table 2 Policy implications and agenda for future research

\begin{tabular}{|c|c|}
\hline Authors & Main policy implications \\
\hline $\begin{array}{l}\text { Dilli, Elert, and } \\
\text { Herrmann }\end{array}$ & $\begin{array}{l}\text { No "perfect" institutional constellation exists that } \\
\text { facilitates different types of entrepreneurship equally; } \\
\text { there is a trade-off between targeting policy reforms to } \\
\text { achieve the desirable entrepreneurship type (radical or } \\
\text { incremental, for instance) and the broader societal wel- } \\
\text { fare from such policies. }\end{array}$ \\
\hline Operti & $\begin{array}{l}\text { Private capital in society (even of criminal origin) drives } \\
\text { entrepreneurial finance. Clamping down on organized } \\
\text { crime triggers productive processes of creative } \\
\text { destruction only when the state or local institutions can } \\
\text { adequately redeploy the confiscated assets to productive } \\
\text { ends. }\end{array}$ \\
\hline $\begin{array}{l}\text { Grilli, Mrkajic, and } \\
\text { Latifi }\end{array}$ & $\begin{array}{l}\mathrm{VC} \text { is mostly influenced by slowly evolving and } \\
\text { hard-to-change institutional features. A European } \\
\text { "institutional misalignment" towards VC is a key reason } \\
\text { behind the endemic lack of this type of finance in most } \\
\text { European countries. The only changeable formal insti- } \\
\text { tution that is found to play a non-negligible role is the tax } \\
\text { code. By contrast, reforms aiming at increasing flexibil- } \\
\text { ity in labor markets or investor protection do not matter } \\
\text { as to VC activity. }\end{array}$ \\
\hline $\begin{array}{l}\text { Henrekson and } \\
\text { Sanandaji }\end{array}$ & $\begin{array}{l}\text { Lower stock option taxation to promote } \mathrm{VC} \text { activity, also in } \\
\text { the European context. }\end{array}$ \\
\hline
\end{tabular}

Estrin, Gozman, and Khavul

Fritsch and Wyrwich

Darnihamedani, Block, Hessels, and Simonyan

Dilli and Westerhuis

Held, Herrmann, and van Mossel effects on innovative entrepreneurship. Institute formal institutions that steer informal institutions in a direction that encourages the evolution of an entrepreneurial culture.

Startup costs may prevent unproductive entry, corporate taxation hurts innovative entrepreneurship. To promote innovative entrepreneurship, one should lower taxes, not barriers to entry. Or more generally, recurring costs that lower the upside and reinvestment potential are more important than one-time costs. Therefore, using taxation on property and on consumption rather than on profits (that can be reinvested) can be effective mechanisms to promote innovative ventures.

Closing the gender gap in science education is beneficial to stimulate entrepreneurial engagement in knowledge-intensive sectors and high-growth entrepreneurial activity. Policies should target gender differences that emerge at early stage of life course to narrow the gender gap in science at tertiary level.

Labor-market rigidity inhibits growth of new ventures by affecting team formation.
Agenda for research

A historical study of the evolution of institutional diversity constitutes a first important avenue for future research. Furthermore, a multilevel analysis would be desirable, examining how institutions influence individual entrepreneurial behavior not only at the country level, but also at the level of states or regions.

Examine the joint impact of bottom-up and top-down initiatives against organized crime to improve our understanding of complementarities and self-enforcing dynamics. Additional studies of the effectiveness and economic effects of different policy measures combating organized crime.

At the VClevel, there is the need to better understand to what extent different institutional dimensions have disparate effects on the supply side and demand side of $\mathrm{VC}$ and to locate this analysis at the regional level. More generally, it is important to explore if new entrepreneurial finance mechanisms (e.g., crowdfunding) are more suitable than VC in the European landscape.

Explore the importance of VC for innovative entrepreneurship and whether other types of agents can substitute for $\mathrm{VC}$, for example, via fintech and alternative finance, to boost innovative entrepreneurship.

We should identify if and how the UK regulatory approach on equity crowdfunding of "vigilance with temperance" can be successfully exported to other institutional contexts.

It is important to identify the sources of a regional culture of entrepreneurship and the mechanisms through which it is transferred over time.
The paper suggests there is an optimal, non-zero barrier to entry and a trade-off may exist between quantity and quality of entrepreneurship. To find that optimum would be an interesting area for future research. Also, entrepreneurs are a heterogeneous group and it is valuable to study important sub-groups and it would be interesting to investigate the impact of other regulations, such as labor regulations on entrepreneurs' propensity to innovate and how they moderate the effects of start-up costs and taxes.

More research is required on the relationship between the gender gap in science and entrepreneurship for the high-skilled migrant-receiving countries.

Extend database across countries to assess the impact of different labor-market institutions. Investigate further drivers of team formation, e.g., internal and 
Table 2 (continued)

\begin{tabular}{|c|c|c|}
\hline Authors & Main policy implications & Agenda for research \\
\hline & & $\begin{array}{l}\text { time-dependent characteristics of ventures, as well as } \\
\text { linking team formation processes to specific } \\
\text { outcomes, such as venture success. }\end{array}$ \\
\hline $\begin{array}{l}\text { Fu, Larsson, and } \\
\text { Wennberg }\end{array}$ & $\begin{array}{l}\text { Labor market institutions may lock people into their career, } \\
\text { either as habitual entrepreneur or as employee. The first } \\
\text { could be considered a good thing, but generally, mobility } \\
\text { is preferred. One-sided liberalization of labor market } \\
\text { protection of temporary workers is not helpful. It forces } \\
\text { more necessity entrepreneurship and does not contribute } \\
\text { to more productive habitual entrepreneurs. }\end{array}$ & $\begin{array}{l}\text { It remains to be researched to what extent one-sided } \\
\text { liberalization of temporary contracts pushes individ- } \\
\text { uals into involuntary entrepreneurship. Investigate } \\
\text { how labor market regulations affect entrepreneurial } \\
\text { venturing through other channels such as team for- } \\
\text { mation (Held et al. 2018) and start-up growth. }\end{array}$ \\
\hline $\begin{array}{l}\text { Bosma, Content, } \\
\text { Sanders, and } \\
\text { Stam }\end{array}$ & $\begin{array}{l}\text { Entrepreneurship contributes to growth when better } \\
\text { institutions drive entrepreneurial activity. To promote } \\
\text { productive entrepreneurial activity, improving the } \\
\text { institutional framework is effective. }\end{array}$ & $\begin{array}{l}\text { Test more institutions through different entrepreneurial } \\
\text { activity channels across a broader range of countries } \\
\text { to identify key institutions for the entrepreneurial } \\
\text { ecosystem and inform e.g. index building. }\end{array}$ \\
\hline $\begin{array}{l}\text { Acs, Estrin, } \\
\text { Mickiewicz, and } \\
\text { Szerb }\end{array}$ & $\begin{array}{l}\text { Entrepreneurial activity and institutional quality are } \\
\text { complements and need to be developed in tandem. } \\
\text { Promoting new firm formation without improving } \\
\text { institutional context is less effective or even ineffective. }\end{array}$ & $\begin{array}{l}\text { Further develop robust indices for entrepreneurial } \\
\text { activity, its institutional context, and their interplay } \\
\text { and test these in in growth models at the local, } \\
\text { regional, and national level. }\end{array}$ \\
\hline
\end{tabular}

together, the work collected on finance in this issue would strongly support such an experiment in a controlled environment (e.g., regulatory sandboxes).

The papers by Held et al. (2018) and Fu et al. (2018) add the dimension of labor market institutions, where Held et al. specifically focus on team formation in earlystage ventures. More liberal labor markets make it easier to form and dissolve teams, i.e., to upscale, downscale, and/or change the human capital composition of the venture. This flexibility undoubtedly is valuable to the entrepreneur. Stringent employment protection can impede venture formation and value creation as it often entails liabilities and risks that employers are forced to shoulder. One could compare this to the value of a house when it is rented out. The tenants' rights reduce the value of the property. Perhaps the stringency of labor market regulations thus serves as a barrier to entry, raising the required quality of entrepreneurship, but more likely, it acts as a penalty on growth. The employees are therefore "protected" out of a job and perhaps miss out on career opportunities they would have gladly explored. Fu et al. (2018) confirm that strict labor market regulations reduce the mobility between entrepreneurship and employment, although their focus is on habitual entrepreneurs. They show that stringent employment protection makes habitual entrepreneurs more likely to return to entrepreneurial venturing. Their analysis also makes clear that liberalizing the labor market for temporary workers alone is not helpful in promoting productive entrepreneurship. Instead, that will create a deeper divide and more dual labor market that locks many workers out of both high-quality employment and entrepreneurship, thus forcing more people into a vicarious and uncertain existence as a necessity self-employed or on-demand worker.

In this area, a great deal of policy experimentation and further research is needed. Labor market reforms should in general be aimed at liberalization but more importantly at decoupling rights and obligations from labor market status. This is particularly relevant in social security, where rights of employees represent costs or risks for their employers. Experiments in that general direction also set an important agenda for entrepreneurship research. Such reforms, though perhaps seemingly not directly related to entrepreneurship, may very well be much more effective than setting up tech transfer offices and incubators, starting government venture capital funds, or adding entrepreneurship to school curricula.

The two papers (Acs et al. 2018 and Bosma et al. 2018) that conclude this special issue both conclude that without a supportive institutional framework, entrepreneurial activity will not contribute to economic growth. The direct policy implications of these papers are thus rather broad, but the research agenda these papers usher in is both profound and wide-ranging. Both papers show that traditional, one-dimensional measures of entrepreneurship do 
not correspond well to the entrepreneurship Joseph Schumpeter envisioned. This makes these indicators of entrepreneurial activity less suitable as targets for evaluating the effectiveness of policy. For example, the one-sided labor market liberalization in the Netherlands has led to an explosion in self-employment but resulted in little or no effect on economic growth and innovation. It is well known that only a small share of new firms and ventures survive, and out of these survivors, most remain small. It is only the few gazelles, and most spectacularly the unicorns, that create significant impact and drive the inclusive, sustainable growth countries look for. The relevant question is not only how to promote entrepreneurship at the base, but also how to boost entrepreneurs with the inherent potential to reach the top. If the institutional framework in which the newly founded ventures emerge and get selected is poorly designed, promoting self-employment at the base will result in naught. The real challenge in this area will be to systematically investigate what institutions support productive entrepreneurship in what way, for example, following the approach in Bosma et al. (2018). Furthermore, this can inform the effort to develop better policy evaluation tools that capture the systemic nature and quality of the entrepreneurial ecosystem as proposed in Acs et al. (2018). Institutional reforms can then be evaluated and be based on an improved understanding of the complex interplay of the various actors and structures constituting the entrepreneurial ecosystem. This will prove an essential step in giving entrepreneurship its proper place in the study of economic growth, where knowledge creation still seems to rule supreme.

A cursory look at Table 2 is sufficient to conclude that in both empirical and theoretical work on entrepreneurship, we increasingly realize that the relevant ecosystem is complex, multilayered, and highly path dependent. This implies that we should be humble when it comes to policy prescriptions but ambitious in our research. That is, to make small improvements to this complex of interlocked institutions, reforms need to be well tailored, well designed, and well implemented to reach even modest objectives. Still, it is both urgent and desirable to make the effort. We hope this special issue will inspire both researchers and policy makers to engage in that challenge.

Acknowledgements We thank the editors for their encouragement and for giving us the opportunity to put together this special issue. We acknowledge financial support from the EU project Financial and Institutional Reforms for an Entrepreneurial Society (FIRES) (grant agreement number 949378).
Open Access This article is distributed under the terms of the Creative Commons Attribution 4.0 International License (http:// creativecommons.org/licenses/by/4.0/), which permits unrestricted use, distribution, and reproduction in any medium, provided you give appropriate credit to the original author(s) and the source, provide a link to the Creative Commons license, and indicate if changes were made.

\section{References}

Papers included in this special issue

Acs, Z. J., Estrin, S., Mickiewicz, T., \& Szerb, L. (2018). Entrepreneurship, institutional economics and economic growth: an ecosystem perspective. https://doi.org/10.1007 /s11187-018-0013-9.

Bosma, N., Content, J., Sanders, M., \& Stam, E. (2018). Institutions, entrepreneurship, and economic growth in Europe. https://doi. org/10.1007/s11187-018-0012-x.

Darnihamedani, P., Block, J. H., Hessels, J., \& Simonyan, A. (2018). Taxes, startup costs, and innovative entrepreneurship. https://doi.org/10.1007/s11187-018-0005-9.

Dilli, S., \& Westerhuis, G. (2018). How institutions and gender differences in education shape entrepreneurial activity: a cross-national perspective. https://doi.org/10.1007/s11187018-0004-x.

Dilli, S., Elert, N., \& Herrmann, A. (2018). Varieties of entrepreneurship: exploring the institutional foundations of different entrepreneurship types through "varieties-ofcapitalism" arguments. https://doi.org/10.1007/s11187018-0002-z.

Estrin, S., Gozman, D. \& Khavul, S. (2018). The evolution and adoption of equity crowdfunding: entrepreneur and investor entry into a new market. https://doi.org/10.1007/s11187-0180009-5.

Fritsch, M., \& Wyrwich, M. (2018). Regional knowledge, entrepreneurial culture and innovative start-ups over time and space - an empirical investigation. https://doi.org/10.1007 /s11187-018-0016-6.

Fu, K., Larsson, A. S., \& Wennberg, K. (2018). Habitual entrepreneurs in the making: how labor market rigidity and employment influence entrepreneurial re-entry. https://doi. org/10.1007/s11187-018-0011-y.

Grilli, L., Mrkajic, B., \& Latifi, G. (2018). Venture capital in Europe: social capital, formal institutions and mediation effects. https://doi.org/10.1007/s11187-018-0007-7.

Held, L., Herrmann, A., \& van Mossel, A. (2018). Team formation processes in new ventures. https://doi.org/10.1007/s11187018-0010-z.

Henrekson, M., \& Sanandaji, T. (2018). Stock option taxation: a missing piece in European innovation policy? https://doi. org/10.1007/s11187-018-0008-6.

Operti, E. (2018). Tough on criminal wealth? Exploring the link between organized crime's asset confiscation and regional entrepreneurship. https://doi.org/10.1007/s11187-018-0003y. 
Additional references

Acs, Z. J., \& Sanders, M. (2013). Knowledge spillover entrepreneurship in an endogenous growth model. Small Business Economics, 41(4), 775-795. https://doi.org/10.1007/s11187013-9506-8.

Acs, Z. J., Audretsch, D. B., Braunerhjelm, P., \& Carlsson, B. (2009). The knowledge spillover theory of entrepreneurship. Small Business Economics, 32(1), 15-30. https://doi.org/10.1007 /s11187-008-9157-3.

Acs, Z. J., Audretsch, D. B., \& Lehmann, E. (2013). The knowledge spillover theory of entrepreneurship. Small Business Economics, 41(4), 757-774. https://doi.org/10.1007 /s11187-013-9505-9.

Acs, Z. J., Autio, E., \& Szerb, L. (2014). National systems of entrepreneurship: measurement issues and policy implications. Research Policy, 43(3), 476-494. https://doi.org/10.1016/j. respol.2013.08.016.

Aghion, P., \& Howitt, P. (1992). A model of growth through creative destruction. Econometrica, 60(2), 323-351. https://doi.org/10.3386/w3223.

Anderson, A. R., \& Starnawska, M. (2008). Research practices in entrepreneurship: problems of definition, description and meaning. International Journal of Entrepreneurship and Innovation, 9(4), 221-230. https://doi.org/10.5367 /000000008786208731.

Andersson, M., \& Koster, S. (2011). Sources of persistence in regional start-up rates - evidence from Sweden. Journal of Economic Geography, 11(1), 179-201. https://doi. org/10.1093/jeg/lbp069.

Audretsch, D. B. (2007). The entrepreneurial society. Oxford: Oxford University Press.

Audretsch, D. B., \& Thurik, A. R. (2000). Capitalism and democracy in the 21st century: from the managed to the entrepreneurial economy. Journal of Evolutionary Economics, 10(12), 17-34. https://doi.org/10.1007/s001910050003.

Audretsch, D. B., Carree, M. A., van Stel, A. J., \& Thurik, A. R. (2002). Impeded industrial restructuring: the growth penalty. Kyklos, 55(1), 81-97.

Autio, E. (2016). Entrepreneurship support in Europe: trends and challenges. Technical report. London: Imperial College.

Baumol, W. J. (1990). Entrepreneurship: productive, unproductive, and destructive. Journal of Political Economy, 98(5), 893-921. https://doi.org/10.1016/0883-9026(94)00014-X.

Baumol, W. J., Litan, R. E., \& Schramm, C. J. (2007). Good capitalism, bad capitalism, and the economics of growth and prosperity. New Haven: Yale University Press.

Bjørnskov, C., \& Foss, N. J. (2013). How strategic entrepreneurship and the institutional context drive economic growth. Strategic Entrepreneurship Journal, 7(1), 50-56.

Blackburn, R. A., \& Schaper, M. (2016). Government, SMEs and entrepreneurship development: policy, practice and challenges. London: Routledge.

Braunerhjelm, P., \& Eklund, J. E. (2014). Taxes, tax administrative burdens and new firm formation. Kyklos, 67(1), 1-11.

Carlsson, B. (1999). Small business, entrepreneurship, and industrial dynamics. In Z. J. Acs (Ed.), Are small firms important? Their role and impact. Dordrecht: Kluwer.
Djankov, S., La Porta, R., Lopes de Silanes, F., \& Shleifer, A. (2002). The regulation of entry. Quarterly Journal of Economics, 117(1), 1-37. https://doi.org/10.1162/003355302753399436.

Elert, N., Henrekson, M., \& Stenkula, M. (2017). Institutional reform for innovation and entrepreneurship - an agenda for Europe. New York: Springer.

Fotopoulos, G., \& Storey, D. J. (2017). Persistence and change in interregional differences in entrepreneurship: England and Wales, 1921-2011. Environment and Planning A, 49(3), 670-702. https://doi.org/10.1177/0308518X16674336.

Fritsch, M., Obschonka, M., \& Wyrwich, M. (2017). Histories of regional entrepreneurship, entrepreneurial cultures, innovation, and growth - an analysis for Germany. Jena: University of Jena (mimeo).

Gentry, W. M., \& Hubbard, R. G. (2000). Tax policy and entrepreneurial entry. American Economic Review, 90(2), 283287 http://www.jstor.org/stable/117236.

Gompers, P. A., \& Lerner, J. (2001). The money of invention: how venture capital creates new wealth. Cambridge: Harvard Business School Press.

Hall, R. E., \& Jones, C. I. (1999). Why do some countries produce so much more output per worker than others? Quarterly Journal of Economics, 114(1), 83-116. https://doi.org/10.1162 /003355399555954.

Hall, P. A., \& Soskice, D. (2001). Varieties of capitalism: the institutional foundations of comparative advantage. Oxford: Oxford University Press.

Henrekson, M. (2014). How labor market institutions affect job creation and productivity growth. IZA World of Labor, 38, 110. https://doi.org/10.15185/izawol.38.

Henrekson, M., \& Johansson, D. (2009). Competencies and institutions fostering high-growth firms. Foundations and Trends in Entrepreneurship, 5(1), 1-80. https://doi.org/10.1561 /0300000026.

Henrekson, M. \& Sanandaji, T. (2017). Schumpeterian entrepreneurship in Europe compared to other industrialized regions. IFN Working Paper No. 1170. Stockholm: Research Institute of Industrial Economics.

Ilmakunnas, P., \& Kanniainen, V. (2001). Entrepreneurship, economic risks, and risk insurance in the welfare state: results with OECD data 1978-93. German Economic Review, 2(3), 195-218.

Islam, N. (1995). Growth empirics: a panel data approach. Quarterly Journal of Economics, 110(4), 1127-1170. https://doi.org/10.2307/2946651.

Kirzner, I. M. (1973). Competition and entrepreneurship. Chicago: University of Chicago Press.

Klapper, L., Laeven, L., \& Rajan, R. (2006). Entry regulation as a barrier to entrepreneurship. Journal of Financial Economics, 82(3), 591-629. https://doi.org/10.1016/j. jfineco.2005.09.006.

Liebregts, W. J., \& Stam, E. (2016). Employment protection and entrepreneurship: unpacking the effects of employment protection legislation on the allocation of entrepreneurial activity in society. Working paper no. 16-08, Utrecht School of Economics. Utrecht: Utrecht University.

Lundström, A., \& Stevenson, L. A. (2005). Entrepreneurship policy: theory and practice. International studies in entrepreneurship. New York: Springer. 
Mankiw, N. G., Romer, D., \& Weill, D. N. (1992). A contribution to the empirics of economic growth. Quarterly Journal of Economics, 107(2), 407-437. https://doi.org/10.2307/2118477.

Niehof, J. (1999). Barriers for hiring personnel. Research report 9807/E. Zoetermeer: EIM Business and Policy Research.

North, D. C. (1991). Institutions. Journal of Economic Perspectives, 5(1), 97-112. https://doi.org/10.1257 /jep.5.1.97.

OECD. (1998). Fostering entrepreneurship. Paris: OECD.

OECD (2000). "Science, technology and innovation in the new economy". OECD Policy Brief, September.
OECD. (2003). The sources of economic growth in the OECD countries. Paris: OECD.

Schumpeter, J. A. (1934-1911). The theory of economic development: an inquiry into profits, capital, credit, interest, and the business cycle. Cambridge: Harvard University Press.

van Stel, A., Storey, D., \& Thurik, A. R. (2007). The effect of business regulations on nascent and young business entrepreneurship. Small Business Economics, 28(2-3), 171-186. https://doi.org/10.1007/s11187-006-9014-1. 